\title{
Kinetic modeling of ascorbic acid loss in baobab drink at pasteurization and storage temperatures.
}

\author{
Abioye, Adekanmi O.*, Abioye, Victoria F., Ade-Omowaye, Beatrice I.O. and \\ Adedeji,Akinbode A. \\ Department of Food Science and Engineering, Ladoke Akintola University of Technology, P.M.B. 4000,
}

Ogbomoso, Nigeria.

\begin{abstract}
The degradation kinetics of ascorbic acid was determined in baobab drink during pasteurization and storage temperatures at $60-90^{\circ} \mathrm{C}$ for 3 hours and $0-40^{\circ} \mathrm{C}$ for 5 weeks respectively. The loss of ascorbic acid at all temperatures followed the first order kinetic model as the coefficient of determination (i.e. $R^{2}$-value) $\geq 0.953$. Rate constants of ascorbic acid degradation ranged from $9.72-26.31 \times 10^{-3} /$ minute and $5.266-29.95 \times 10^{-3} /$ day during pasteurization and storage respectively. Decimal reduction time (D-value) and half-life ranged between $87.52-236.87$ and $26.35-71.30$ minutes and $76.89-437.78$ and $23.15-131.78$ days for pasteurization and storage temperatures respectively The temperature dependence of degradation reaction was well described by the Arrhenius relationship. The activation energy, $Q_{10}$ factor, and Z-value obtained ranged from $24.24-58.66$ $\mathrm{kJ} / \mathrm{mol}, 1.06-1.58$ and $4.74-7.96^{\circ} \mathrm{C}$ for the temperature range within which experiments were carried out. The values were similar to many others reported for food systems in literatures.
\end{abstract}

Keywords: Baobab drink, ascorbic acid, , rate constants, Arrhenius plot, activation energy.

\section{Introduction}

The African baobab belongs to the family Bombaceae and the genus Adansonia. It is a tree often associated with dry savannah and occurs naturally in most countries of the south of Sahara [1]. It possesses a unique fruit type with woody pericarp surrounding a whitish powdery appearance, slightly sour taste and spongy pulp with manifold seeds [2]. Leaves, bark and fruits of this tree are traditionally employed in several African regions as foodstuffs and for medicinal purposes, and for that reason baobab is also named "the small pharmacy" or "chemist tree" [3,4]. The native African populations commonly use the baobab fruit as famine food to prepare decoctions, sauces, ice-creams, jams and natural refreshing drink, due to its nutritional properties $[5,6,7,8,9,10]$. The pulp is therapeutically employed as febrifuge, analgesic, anti-diarrhea / antidysentery and for treatment of smallpox and measles [4].

Nutritional analysis of baobab fruit pulp has shown that the fruit is an excellent source of pectins, calcium, ascorbic acid and iron [11]. ascorbic acid content of baobab fruit pulp compared with oranges by Manfredini et al, [12] and was shown to be at least three times higher $(150-499 \mathrm{mg} / 100 \mathrm{~g}$ vs $46 \mathrm{mg} / 100 \mathrm{~g})$. Nour et al, [13] reported that the ascorbic acid content of baobab fruit pulp was $300 \mathrm{mg} / 100 \mathrm{~g}$ whereas data from Wilkinson [14] shows that the vitamin levels ranges from 74 to $163 \mathrm{mg} / 100 \mathrm{~g}$. The recommended daily allowance (RDA) for ascorbic acid is $75 \mathrm{mg}$ for women and $90 \mathrm{mg}$ for men, and so $40 \mathrm{~g}$ of fruit pulp would give at least recommended daily amount of ascorbic acid.

Ascorbic acid is an important component of our nutrition and used as additive in many foods because of its antioxidant capacity. Thus, it increases quality and technological properties of food as well as nutritional value $[15,16]$. However, ascorbic acid is known to be a vitamin sensitive to a number of factors, including $\mathrm{pH}$, moisture content, oxygen, temperature and light [17]. Degradation of ascorbic acid proceeds both aerobic and anaerobic pathways $[18,19]$ and depends upon many factors such as oxygen, heat, light [20), storage temperature and storage time [21,22]. Oxidation of ascorbic acid occurs mainly during the processing of juices [18], whereas, anaerobic degradation of ascorbic acid mainly appears during storage $[16,19,23]$ which is especially observed in thermally preserved juices. Due to these afore-mentioned reasons, it is generally observed that, if ascorbic acid is well retained, the other nutrients are also well retained [24]. Hence, ascorbic acid is usually considered as an index of nutrient quality during processing and storage of foods [25].

In modern food technology, the trend is to maximize the nutrients retention in both processing and storage. Kinetic studies help engineers and scientists to optimize processing systems and design processes, to improve or optimize existing processes and develop control systems for processing operations by finding rates of reaction that occur during heat processing operations [26]. Knowledge of the rates of various reactions helps to predict how quick the reaction mixture is able to move to its equilibrium condition and its mechanism [27].The kinetic modeling has been widely used to evaluate thermal stability of ascorbic acid in different food systems such as orange serum [9]; orange juice [17,28]; orange-carrot juice [29]; lemon juice [20,30]; citrus 
Kinetic modeling of ascorbic acid loss in baobab drink at pasteurization and storage temperatures.

juice concentrates [31,32]; pumpkin [33]; potato [34] and guava juice [35]. The dearth of information on degradation of ascorbic acid in baobab drink and associated products indicates the need for studies along that line.

Therefore, this study was undertaken to determine the kinetic parameters for ascorbic acid degradation in baobab drink at processing (pasteurization) $\left(60-90{ }^{\circ} \mathrm{C}\right)$ and storage $\left(0-40{ }^{\circ} \mathrm{C}\right)$ temperatures.

\subsection{Materials}

\section{Materials And Methods}

Baobab fruits were harvested at maturity from parent trees found around LAUTECH, Ogbomoso, Nigeria. All chemicals/reagents used were of analytical grade

\subsection{Preparation of Baobab Drink}

Ripe Baobab fruits were manually broken and pulp was manually separated from the seeds. Thereafter, the fiber in the pulp was reduce by passing it through $250 \mu \mathrm{m}$ British standard sieve and packed in low-density polyethylene bag until further use. Baobab drink was prepared by mixing $200 \mathrm{~g}$ pulp with $1000 \mathrm{ml}$ distill water so that more than daily recommended dose of ascorbic acid can be adequately provided for in approximately $200 \mathrm{ml}$ of the drink [1,12]. The mixture was homogenized using a kitchen blender (Binatone model BLG - 401) for 5 minutes and pasteurized at $80^{\circ} \mathrm{C}$ for 15 min. The drink was aseptically packaged in plastic bottles and stored in freezer until further use.

\subsection{Thermal treatments}

Stability of ascorbic acid at different temperatures was determined with little modifications according to Mok \& Hettiarachchy [36]. In this method, $5 \mathrm{ml}$ of baobab drink was poured into screw capped test tube and were heated in a thermostatically controlled water bath with an accuracy of $\pm 2{ }^{\circ} \mathrm{C}$ at $60,70,80$ and $90{ }^{\circ} \mathrm{C}$ for processing temperatures while samples for storage temperatures were kept at freezing temperature $\left(-5^{\circ} \mathrm{C}\right)$, refrigeration temperature $\left(5^{\circ} \mathrm{C}\right)$, on laboratory table $\left(25^{\circ} \mathrm{C}\right)$ and at $40^{\circ} \mathrm{C}$ in a thermostatically controlled incubator. Samples in test tubes were taken for analysis at 30 minutes interval for 180 minutes and every week for 5 weeks for processing and storage temperatures respectively. Each sample temperature was quickly brought to room temperature either by cooling in an ice bath or warming in a water bath in order not to interfere the course of determination of ascorbic acid content.

\subsection{Ascorbic acid determination}

Determination of ascorbic acid was done using 2 -6- Dicholoro-phenol Indophenol dye reagent according to the method described by Ruucke [37]. The dye was standardized so that one gram of ascorbic acid is equivalent to one $\mathrm{ml}$ of the dye used. About $5 \mathrm{ml}$ of sample was blended with about $20 \mathrm{ml}$ of $0.4 \%$ oxalic acid for two minutes in a blender and then filtered through Whatman filter paper (No. 1). The filtrate was made up to $50 \mathrm{ml}$ with $0.4 \%$ oxalic acid. Ascorbic acid in $4 \mathrm{ml}$ filtrate was titrated against standard 2-6-Dichlorophenol Indophenol. The experimental results are shown in TABLE 1.

\subsection{Kinetic modeling}

Degradation of ascorbic acid is described using the process reaction rate and the influence of temperature on the reaction rate. The kinetic parameters used are reaction rate constant $(\mathrm{k})$ and the Arrhenius activation energy $\left(\mathrm{E}_{\mathrm{a}}\right)$ which were analyzed as described by van Boekel [38]. A first order degradation was presumed in order to arrive at the reaction rate constant as:

$-d C / d t=k C$

where $\mathrm{C}$ is the instantaneous concentration of ascorbic acid, $\mathrm{t}$ is time and $\mathrm{k}$ is the reaction rate constant $\left(\mathrm{time}^{-1}\right)$, By separation of variable, integration of Eq.(1) yields:

$C=C_{o} \exp (-k t)$

Linearization of equation 2 by taking natural logarithm of both sides yields;

$\operatorname{Ln}\left(C / C_{o}\right)=-k t$

For first order reaction, a plot of ' $\operatorname{Ln}\left(C / C_{o}\right)$ ' against process time ' $\mathrm{t}$ ' will be a straight line as shown in Fig. 1

$\& 2$, and the rate constant is represented by the slope which are reported with their respective correlation coefficients $\left(R^{2}\right.$ value) in TABLE 1.

Decimal reduction time (or $\mathrm{D}_{\text {value }}$ ) is defined as the time required for ascorbic acid to reduce by one log-cycle at a particular temperature and it is calculated from the rate constant as;

$D_{\text {value }}=\operatorname{Ln}(10) / k$ 
Half-life, the time required for ascorbic acid to degrade to $50 \%$ of its original value and was calculated from the rate constant as:

$t_{1 / 2}=\operatorname{Ln}(0.5) / k$

Influence of temperature on ascorbic acid degradation was determined using the Arrhenius equation:

$k=k_{o} \exp \left(-E_{a} / R T\right)$

where, $k_{o}$ is frequency factor or pre-exponential constant; $E_{a}(\mathrm{~kJ} / \mathrm{mol})$ is the activation energy of the reaction; $T$ is the absolute temperature of the medium; and $\mathrm{R}$ is the universal gas constant $(8.314 \mathrm{~kJ} / \mathrm{mol} . \mathrm{K})$.

Linearization of Eq. (6) by taking natural logarithm of both sides yields;

$$
L n k=L n k_{o}-E_{a} / R T
$$

The parameters $E_{a}$ and $k_{o}$ in equations (6) or (7) are of fundamental interest since they both represent the activation energy and pre-exponential constant associated with a reference absolute temperature for activation reaction, respectively. Both values were obtained from the plots of Lnk versus $1 / T$ values. Activation energies $E_{a}$ $(\mathrm{kJ} / \mathrm{mol})$ was calculated as a product of universal gas constant, $\mathrm{R}(8.314 \mathrm{~kJ} / \mathrm{mol} . \mathrm{K})$ and the slope of the graph obtained by plotting 'Lnk' versus ' $1 / \mathrm{T}$ '. Fig. 3 and 4 shows the Arrhenius plots for ascorbic acid degradation in baobab drink under pasteurization and storage conditions.

Temperature quotient $\left(\mathrm{Q}_{10}\right)$ values, the number of times ascorbic acid degrades with a $10{ }^{\circ} \mathrm{C}$ change in temperature, were also calculated for the temperature ranges of $-5-40{ }^{\circ} \mathrm{C}$ and $60-90{ }^{\circ} \mathrm{C}$ It is expressed as (Toledo, 1991):

$Q_{10}=e^{\left.\left(E_{a} / R\right)\left(10 T_{21} /\right] T\right)}$

The $\mathrm{z}$ value, the temperature change needed to change ascorbic acid degradation rate by a factor of 10 . The $\mathrm{z}$ value has also been used to express the temperature dependence of degradative reactions occurring in foods during processing and storage. The $\mathrm{z}$ value expressed in terms of the $\mathrm{Q}_{10}$ is as follows:

$z=10 \ln (10) / \ln \left(Q_{10}\right)$

\subsection{Statistical Analysis}

Each sample was analyzed in triplicate then averaged. Linear regression analysis was used to obtain kinetic parameters of Baobab drink samples using Microsoft Excel software (Version 7, Microsoft Corporation, Redmond, WA, USA).

\section{Results And Discussion}

\subsection{Amount of ascorbic acid in baobab drink at isothermal conditions.}

TABLES 1 and 2 show the effect of heat treatments at different temperatures $-5-40{ }^{\circ} \mathrm{C}$ (storage) and $60-90{ }^{\circ} \mathrm{C}$ (pasteurization) over different time periods on the initial concentration of ascorbic acid. Initial ascorbic acid contents of baobab drink varied between 125.00 and $137.29 \mathrm{mg} / 100 \mathrm{ml}$ (TABLE 1 and 2). This confirmed the significance of baobab fruit pulp as a popular ingredient in local drinks amongst rural dwellers in areas where they are found and exploited [39]. Ascorbic acid content of the samples decreased to 103.17, 74.67, $59.17,39.00 \mathrm{mg} / 100 \mathrm{ml}$ and $22.83,11.38,5.50,1.50 \mathrm{mg} / 100 \mathrm{ml}$ after a five week storage at $-5,5,25$ and $40{ }^{\circ} \mathrm{C}$ and holding at potential pasteurization temperatures of $60,70,80,90{ }^{\circ} \mathrm{C}$ respectively. It was observed as expected from the study that ascorbic acid decreased with increasing temperature [31] and retention of ascorbic acid (\%) in those samples at $-5,5,25$ and $40{ }^{\circ} \mathrm{C}$ were $82.53,59.73,47.33,31.22$ and $16.63,8.29,4.01,1.09$ respectively. At pasteurization temperatures, the loss of ascorbic acid in baobab drink was highest especially at $90^{\circ} \mathrm{C}$ compared to the loss at storage temperatures. Moreover, half-life of ascorbic acid in the drink was found higher at storage temperature of $-5^{\circ} \mathrm{C}$.

\subsection{Kinetic data for loss of ascorbic acid in baobab drink.}

A first order degradation was assumed in order to determine the reaction rate constants. The plot of natural logarithm of remaining concentration of ascorbic acid i.e. ' $\mathrm{Ln}\left(\mathrm{C} / \mathrm{C}_{\mathrm{o}}\right)$ ' versus time 't' (Fig. $\left.1 \& 2\right)$, from which rate 
Kinetic modeling of ascorbic acid loss in baobab drink at pasteurization and storage temperatures.

\begin{tabular}{ccccccc}
\multicolumn{6}{l}{ Table 1: Ascorbic acid degradation in baobab drink during storage $(\mathrm{mg} / 100 \mathrm{ml})$} \\
\hline $\begin{array}{c}\text { Temperature } \\
{ }^{\circ} \mathrm{C}\end{array}$ & \multicolumn{7}{l}{ Time (days) } \\
\cline { 2 - 7 } & 0 & 7 & 14 & 21 & 28 & 35 \\
\hline-5 & 125.00 & 121.54 & 117.33 & 113.083 & 109.54 & 103.17 \\
& $(0.500)$ & $(0.711)$ & $(0.577)$ & $(1.377)$ & $(0.315)$ & $(0.688)$ \\
& & & & & \\
& & & & & \\
& 125.00 & 110.42 & 99.88 & 87.63 & 81.75 & 74.67 \\
25 & $(0.500)$ & $(0.629)$ & $(0.650)$ & $(0.696)$ & $(1.639)$ & $(0.764)$ \\
& 125.00 & 104.92 & 88.46 & 77.33 & 69.54 & 59.17 \\
& $(0.500)$ & $(0.722)$ & $(0.938)$ & $(0.577)$ & $(0.641)$ & $(1.041)$ \\
40 & 125.00 & 90.29 & 75.33 & 65.17 & 56.00 & 39.00 \\
& $(0.500)$ & $(4.490)$ & $(1.607)$ & $(0.289)$ & $(2.000)$ & $(0.750)$ \\
\hline
\end{tabular}

Numbers in parenthesis are standard deviations

Table 2: Ascorbic acid degradation in baobab drink during pasteurization $(\mathrm{mg} / 100 \mathrm{ml})$

\begin{tabular}{|c|c|c|c|c|c|c|c|}
\hline \multirow[t]{2}{*}{$\begin{array}{c}\text { Temperature } \\
{ }^{\circ} \mathrm{C}\end{array}$} & \multicolumn{7}{|l|}{$\begin{array}{l}\text { Time } \\
\text { (minutes) }\end{array}$} \\
\hline & 0 & 30 & 60 & 90 & 120 & 150 & 180 \\
\hline 60 & $\begin{array}{r}137.29 \\
(0.711)\end{array}$ & $\begin{array}{c}123.42 \\
(0.878)\end{array}$ & $\begin{array}{c}99.58 \\
(1.010)\end{array}$ & $\begin{array}{c}75.33 \\
(1.258)\end{array}$ & $\begin{array}{c}58.17 \\
(0.764)\end{array}$ & $\begin{array}{c}40.17 \\
(1.155)\end{array}$ & $\begin{array}{c}22.83 \\
(0.577)\end{array}$ \\
\hline 70 & $\begin{array}{l}137.29 \\
(0.711)\end{array}$ & $\begin{array}{c}101.75 \\
(0.750)\end{array}$ & $\begin{array}{c}81.33 \\
(0.289)\end{array}$ & $\begin{array}{c}55.92 \\
(0.722)\end{array}$ & $\begin{array}{c}31.67 \\
(0.764)\end{array}$ & $\begin{array}{c}22.50 \\
(1.000)\end{array}$ & $\begin{array}{c}11.38 \\
(0.545)\end{array}$ \\
\hline 80 & $\begin{array}{l}137.29 \\
(0.711)\end{array}$ & $\begin{array}{c}91.92 \\
(0.722)\end{array}$ & $\begin{array}{c}63.96 \\
(0.072)\end{array}$ & $\begin{array}{c}41.58 \\
(0.520)\end{array}$ & $\begin{array}{c}17.54 \\
(0.286)\end{array}$ & $\begin{array}{c}8.66 \\
(0.764)\end{array}$ & $\begin{array}{c}5.50 \\
(0.500)\end{array}$ \\
\hline 90 & $\begin{array}{r}137.29 \\
(0.711)\end{array}$ & $\begin{array}{c}87.50 \\
(1.000)\end{array}$ & $\begin{array}{c}63.63 \\
(1.192)\end{array}$ & $\begin{array}{c}31.17 \\
(0.577)\end{array}$ & $\begin{array}{c}9.33 \\
(0.289)\end{array}$ & $\begin{array}{c}3.46 \\
(0.938)\end{array}$ & $\begin{array}{c}1.50 \\
(0.500)\end{array}$ \\
\hline
\end{tabular}

*Determined at $\mathrm{pH}$ and soluble solids of 3.20 and $9.00 \mathrm{oBrix}$

Numbers in parenthesis are standard deviations

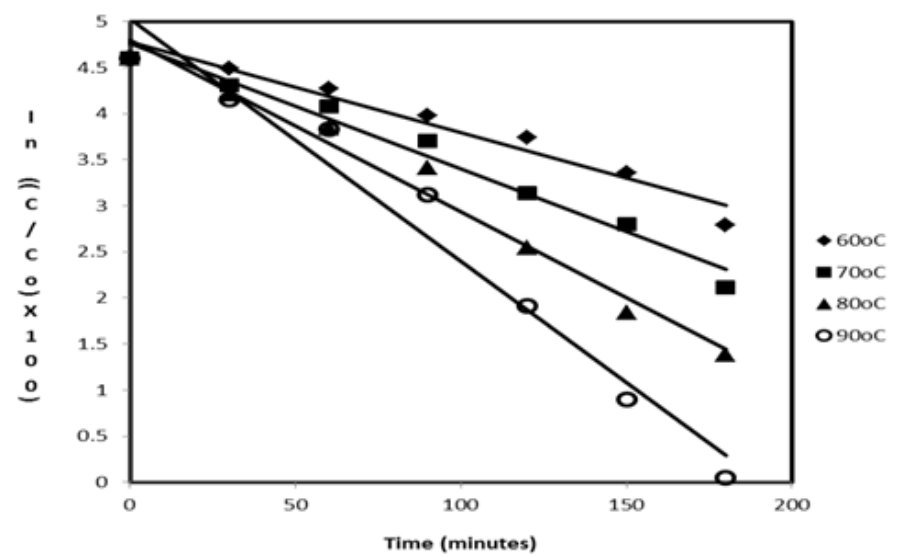

Fig.1: Kinetics of ascorbic acid loss in baobab drink at pasteurization temperatures

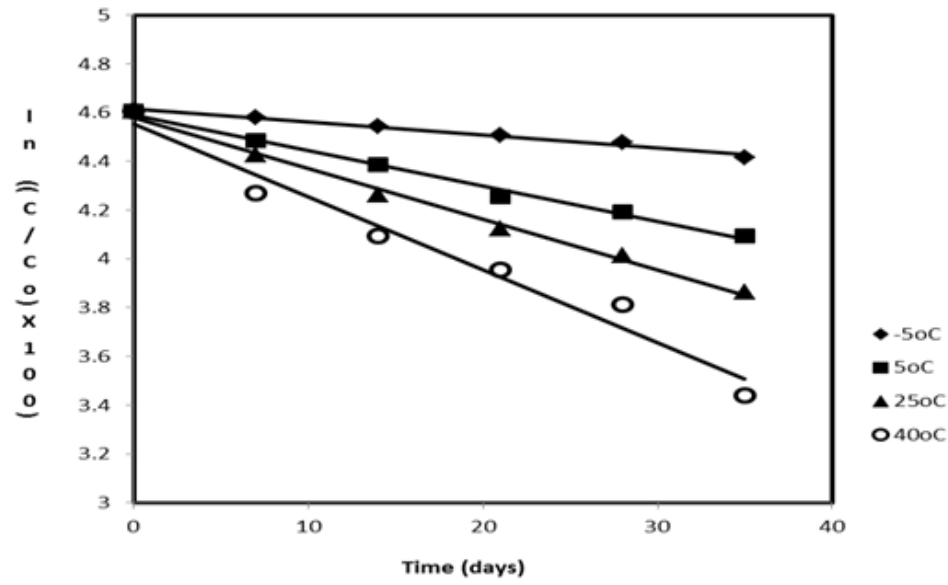

Fig.2: Kinetics of ascorbic acid loss in baobab drink at storage temperatures 
constant, ' $\mathrm{k}$ ' was determined as the slope of the straight line. In addition, the plot yielded high determination coefficients $\left(\mathrm{R}^{2}\right.$ value) between 0.976 and 0.997 from the regression analyses which are indications of validity of first order reaction kinetics for the food system under consideration. This is in agreement with other studies $[17,19,31,40,41]$. However, it has also been reported by other researchers that ascorbic acid degradation also sometimes follows a zero-order [42] or second-order reaction [20,40].

Under storage condition, rate constant, ' $\mathrm{k}$ ' increased from $5.26 \times 10^{-3}$ at $0^{\circ} \mathrm{C}$ to $29.95 \times 10^{-3} /$ day at 40 ${ }^{\circ} \mathrm{C}$. At pasteurization temperatures, $\mathrm{k}$ increased from $9.72 \times 10^{-3}$ at $60^{\circ} \mathrm{C}$ to $26.31 \times 10^{-3} /$ minutes at $90{ }^{\circ} \mathrm{C}$ (TABLE 3 and Figs. 3 \& 4). The higher values of rate constants $\mathrm{k}$ obtained for ascorbic acid degradation at processing temperatures were significant indications of the ease of thermal degradation of this vitamin during heat processing such as pasteurization, sterilization e.t.c. compared with degradation at storage temperatures. This fact is augmented by the low values of decimal reduction time $\left(\mathrm{D}_{\text {value }}\right)$ and half-life at pasteurization temperatures between 87.52 - 236.87 and 26.35 - 71.30 compare with the values at storage temperatures between $76.89-437.78$ and $23.15-131.78$ respectively as shown on TABLE 3 .

\subsection{Temperature dependency of degradation.}

Activation energies were found higher at pasteurization temperatures than that of storage temperatures (TABLE 3 ) as calculated by using Arrhenius plots of ascorbic acid degradation in baobab drinks given in Fig. 3 $\& 4$. It could be interpreted that degradation of ascorbic acid has stronger temperature dependency at pasteurization temperatures than at storage temperatures. This implies that the degradation will progress slowly at low temperatures but fast at high temperatures [43].

Temperature quotient $\left(\mathrm{Q}_{10}\right)$ values (approximately equal to 2 ) validate the principle of preservation that degradation of food nutrients doubles for every $10{ }^{\circ} \mathrm{C}$ change in temperature [44]. This observation reveals the marked influence of elevated temperature during processing and handling of baobab drink..

The $\mathrm{z}$ values $\left(25.96{ }^{\circ} \mathrm{C}\right.$ at storage temperatures and $33.05^{\circ} \mathrm{C}$ at pasteurization temperatures) were related with those reported by Rao et al.[45].

\section{Conclusions}

The influence of pasteurization and storage temperatures on the ascorbic acid degradation was evaluated in this study. Ascorbic acid in baobab drink decreased with increasing temperature. The loss of ascorbic acid in baobab drinks at all temperatures was described well by first-order kinetic model. Since ascorbic acid decomposes easily at high temperatures, baobab drinks showed the highest ascorbic acid destruction at pasteurization temperatures especially between 80 and $90{ }^{\circ} \mathrm{C}$. The drink after pasteurization should hence, be rapidly cooled down to lower temperatures i.e. storage temperature where rate of degradation of ascorbic acid and other nutrients are low.

Table 3: Kinetic parameters for degradation of ascorbic acid in baobab drink at different temperatures

\begin{tabular}{|c|c|c|c|c|c|c|c|}
\hline $\begin{array}{c}\text { Temperature } \\
{ }^{\circ} \mathrm{C}\end{array}$ & $\begin{array}{c}\mathrm{k} \pm \mathrm{s} . \mathrm{d} . \\
\left(\mathrm{x} 10^{-3} \text { day }^{-1}\right)\end{array}$ & $\mathrm{R}^{2}$ & $\begin{array}{l}D_{\text {value }} \\
\text { (day) }\end{array}$ & $\begin{array}{c}t_{1 / 2} \\
\text { (day) }\end{array}$ & $\begin{array}{c}\mathrm{E}_{\mathrm{a}} \\
(\mathrm{kJ} / \mathrm{mol})\end{array}$ & $\mathrm{Q}_{10}$ & $\begin{array}{c}Z_{\text {value }} \\
{ }^{\circ} \mathrm{C}\end{array}$ \\
\hline-5 & $5.26 \pm 0.194$ & 0.991 & 437.78 & 131.78 & \multirow{4}{*}{$\begin{array}{c}24.24 \\
(0.876)\end{array}$} & \multirow{4}{*}{1.06} & \multirow{4}{*}{7.96} \\
\hline 5 & $\begin{array}{l}14.55 \pm \\
0.2960\end{array}$ & 0.996 & 158.28 & 47.65 & & & \\
\hline 25 & $\begin{array}{c}20.75 \pm \\
0.0825\end{array}$ & 0.997 & 110.95 & 33.40 & & & \\
\hline 40 & $\begin{array}{c}29.95 \pm \\
0.346\end{array}$ & 0.985 & 76.89 & 23.15 & & & \\
\hline 60 & $\begin{array}{l}9.72 \pm \\
0.128^{*}\end{array}$ & 0.976 & $236.87^{* *}$ & $71.30^{* *}$ & \multirow{4}{*}{$\begin{array}{c}58.66 \\
(0.868)\end{array}$} & \multirow{4}{*}{1.58} & \multirow{4}{*}{4.74} \\
\hline 70 & $\begin{array}{l}13.62 \pm \\
0.0757^{*}\end{array}$ & 0.987 & $169.11^{* *}$ & $50.91^{* *}$ & & & \\
\hline 80 & $\begin{array}{l}18.67 \pm \\
1.468^{*}\end{array}$ & 0.990 & $123.34 * *$ & $38.51^{* *}$ & & & \\
\hline 90 & $\begin{array}{c}26.31 \pm \\
1.597^{*}\end{array}$ & 0.982 & $87.52^{* *}$ & $26.35^{* *}$ & & & \\
\hline
\end{tabular}

* means minutes-1

** means minutes

s.d. mean standard deviation

Figures in parenthesis in column 6 are coefficient of determinations of Arrhenius plots. 


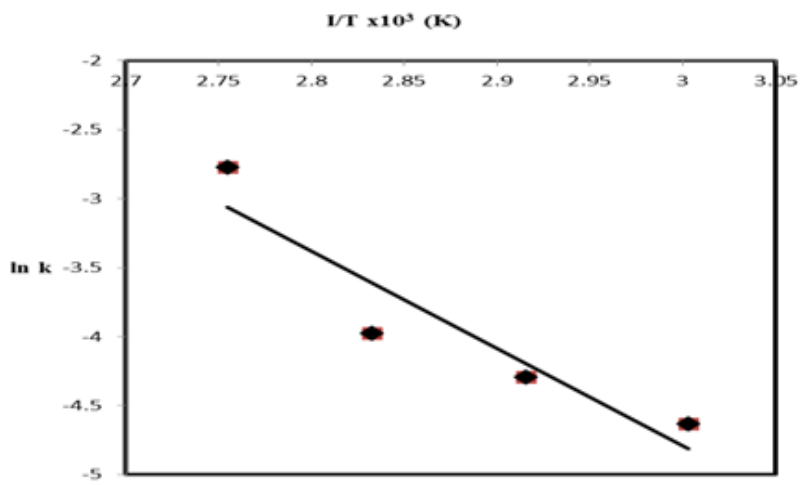

Fig. 3: Arrhenius plot of the ascorbic acid loss rate for baobab drink during pasteurization.

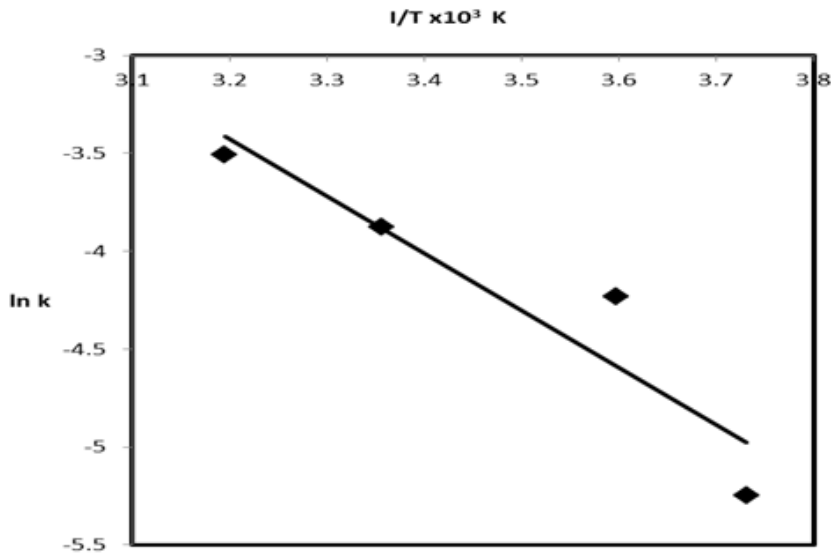

Fig. 4: Arrhenius plot of the ascorbic acid loss rate for baobab drink during storage

\section{References}

[1] M. Sidibe, and J.T. Williams, Baobab (Adansonia digitata L). Fruit for the future. International Centre for Underutilized Crops. Southampton, UK, 2002.

[2] G. Arum, The baobab (Adansonia digitata) for health and completely natural well being. www.baobab fruit co.com, 1989 .

[3] N. L. Etkin, and P. J. Ross, "Food as medicine and medicine as food", Soc. Sci. Med., 16, 1982, 1559-1573.

[4] J. Kerharo, and J. G. Adam, "La pharmacopée sénégalaise traditionelle". Plantes Médicales et Toxiques. Editions Vigot Frères, Paris, 1974, 1012.

[5] A.A. Abdalla, E. H. Nagla, and A.M. Hassan, Production and quality evaluation of Baobab (Adansonia Digitata ) beverage, Journal of Applied Sciences Research 6(6), 2010, 729 -741.

[6] C. Bosch, K. Sie, and B. Asafa, Adansonia digitata L. in G.J.H. Grubben, and O.A. Denton, (Eds.), Plant Resources of Tropical Africa, 2 (Backhuys, Leiden, Netherlands, PROTA Foundation, Wageningen, the Netherlands 2004), 36 - 40

[7] C. T. Lockett, C. C. Calvert, and Grivetti, L. E. Grivetti, Energy and micronutrient composition of dietary and medicinal wild plants consumed during drought. Study of rural Fulani, Northeastern Nigeria. Int'l. Journal Food Science \& Nutrition, 51, 2000, 195-208.

[8] P. Lunven, and J. Adrian, Intérêt alimentaire de la feuille et de la pulpe du fruit de baobab (Adansonia digitata). Ann Nutr. , 14, 1960, 263-276.

[9] I. C. Obizoba, and J. U. Anyika, Nutritive value of baobab milk (gubdi) and mixtures of baobab (Adansonia digitata L.) and hungry rice, acha (Digitaria exilis) flours, Plants Foods for Human Nutrition, 46, 1994, 157-165.

[10] B. M. Nicol, Ascorbic acid content of baobab fruit, Nature, 180 (4580), (1957), 287.

[11] J. Wilkinson, and M. Hall, Baobab fruit - The upside down tree that could turn around the drinks industry, Soft Drink International, April 2007, 26-28.

[12] S. Manfredini, S. Vertuani,, E. Braccioli, aand V. Buzzoni, Antioxidant capacity of Adansonia Digitata fruit pulp and leaves, Acta Phytotherapeutica 2, (2002). 2 - 7.

[13] A.A. Nour, B.I. Magboul, N.H. Kheiri, Chemical composition of baobab fruit (Adansonia digitata), Tropical Science, 22 (4), 1980 , 383-388.

[14] J.A. Willkinson, Baobab dried fruit pulp: Novel food application, http://www.acnfp.gov.uk/assess/ 2006

[15] B. Larisch, U. Groß, and M. Pischetsrieder, On the reaction of L-ascorbic acid with propylamine under various conditions: quantification of the main products by HPLC/DAD, Zeitschrift fur Lebensmittel-Untersuchung Und-Forschung A, 206, 1998, 333 337.

[16] O. Solomon, U. Svanberg, and A. Sahlström, Effect of oxygen and fluorescent light on the quality of orange juice during stora ge at $8{ }^{\circ} \mathrm{C}$, Food Chemistry, 53, 1995, 363-368.

[17] H. S. Lee, and G.A Coates, Vitamin C in frozen, fresh squeezed, unpasteurized, polyethylene-bottled orange juice: A storage study, Food Chemistry, 65, 1999, $165-168$.

[18] F. E. Huelin, Studies on the anaerobic decomposition of ascorbic acid, Food Research, 18, 1953, 633 - 639.

[19] J. R. Johnson, R. J. Braddock, and C.S. Chen, Kinetics of ascorbic acid loss and nonenzymatic browning in orange juice serum: Experimental rate constants, Journal of Food Science, 60(3), 1995, 502-505.

[20] G. L. Robertson, and C.M.L. Samaniego, Effect of initial dissolved oxygen levels on the degradation of ascorbic acid and the browning of lemon juice during storage, Journal of $\quad$ Food Science, 51(1), 1986, $184-187$. 
[21] P.J. Fellers, Shelf life and quality of freshly squeezed, unpasteurized, polyethylene-bottled citrus juice, Journal of Food Science, 53(6), 1988, 1699-1702.

[22] L.R. Gordon, and M.C. Samaniego-Esguerra, Effect of soluble solids and temperature on ascorbic acid degradation in lemon juice stored in glass bottles, Journal of Food Quality, 13, 1990, 361-374.

[23] H. S. Lee, and S. Nagy, Quality changes and nonenzymatic browning intermediates in grapefruit juice during storage Journal of Food Science, 53(1), 1988, 168-171.

[24] J.F. Nicoleti, V. Silveira-Júnior, J. Telis-Romero, and V.R.N. Telis, Influence of drying conditions on ascorbic acid during convective drying of whole persimmons, Drying Technology: An International Journal, 25(5), 2007,691 - 899.

[25] O. Fennema, Loss of vitamins in fresh and frozen foods, FoodTechnology, 31(12), 1977, $32-38$.

[26] K. M. Tarade, R. S. Singhal, R. V. Jayram, and A. B. Pandit, Kinetic degradation of ODAP in Lathyrus sativus L. flour during food processing, Journal of Food Chemistry, 104, 2007, $643-649$.

[27] P. W. Atkins, The rates of chemical reaction. In P. W. Atkins (Ed.), Physical chemistry 4th ed., (Oxford: Oxford University Press, 1990), 778-811.

[28] V.B. Vikram, M.N. Ramesh, and S.G. Prapulla, Thermal degradation kinetics of nutrients in orange juice heated by electromagnetic and conventional method, Journal of Food Engineering, 69, 2005, 31-40.

[29] F. Torregrosa, M.J. Esteve, A. Frigola, and C. Cortes, Ascorbic acid stability during refrigerated storage of orange-carrot juice treated by high pulsed electric filed and comparison with pasteurized juice, Journal of Food Engineering, 73, 2006, 339-345.

[30] M.I. Mazin, and A. Rabah, Kinetics and prediction studies of ascorbic acid degradation in normal and concentrate local lemon juice during storage, Food Chemistry, 101, $2007 \quad 254-259$.

[31] H.S. Burdurlu, N. Koca, and F. Karadeniz, Degradation of vitamin C in citrus juice concentrates during storage, Journal of Food Engineering, 74(2), 2005, $211-216$.

[32] S.B. Hand, K. Nuray, and K. Feryal, Degradation of vitamin c in citrus juice concentrates during storage, Journal of Food Engineering, 74, 2006, 211-216.

[33] O. E. Kajihausa, O. P. Sobukola, M. A. Idowu, and S. O. Awonorin, Nutrient contents and thermal degradation of vitamins in organically grown fluted pumpkin (Telfairia occidentalis) leaves, International Food Research Journal 17, 2010,795 - 807.

[34] N.S. Kincal, and C. Gray, Kinetics of ascorbic acid degradation in potato blanching, International of Food Science and Technology, $22,1987,249-254$

[35] P. Phattaraworrasuth, and N. Chiewchan, Effect of pasteurization on vitamin C content of guava juice, Technology and Innovation for Sustainable Development Conference, Faculty of Engineering, Khon Kaen University, Thailand, 28-29 January $2008,24-26$.

[36] C. Mok, and N. S. Hettiarachchy, Heat stability of sunflower-hull anthocyanin pigment. Journal of Food Science, 56, 1991, 553 555 .

[37] J.A. Ruucke, Chemical Methods of Analysis of Fruits and Vegetables. Publication 154. Dept. of Agric. Canada, 1963.

[38] M. A. J. S. van Boekel, Statistical aspects of kinetic modeling for food science problems. Journal of Food Science, 61, 1996, 477 485 .

[39] J. F. Scheuring, M. Sidibé, and M. Frigg, Malian agronomic research identifies local baobab tree as source of Vitamin A and vitamin C", Sight and Life Newsletter, 1, 1999, 21-24.

[40] A. Abbasi, and M. Niakousari, Kinetics of ascorbic acid degradation in un-pasteurized Iranian lemon juice and concentrate during regular storage conditions. Electronic Journal of Environmental, Agricultural and Food Chemistry. [online]. Available: http://ejeafche.uvigo.es/index.php?option=com_docman\&task=doc_view\&gid=12, 2006.

[41] O.E. Solanke, and S. O. Awonorin, Kinetics of vitamin C degradation in some tropical green leafy vegetables during blanching. Nigeria Food Journal, 20, 2002, $24-31$.

[42] B. M. Laing, D. L. Schlueter, and T. P. Labuza, Degradation kinetics of ascorbic acid at high temperature and water activity, Journal of Food Science, 43(5), 1978, 1440-1443.

[43] M. A. J. S. van Boekel, and L. M. M. Tijskens, Kinetic modeling. In: L.M.M. Tijskens, M. L.A.T. M. Hertog \& B. M. Nicola (Eds.), Food Process Modelling (2nd ed.). England, Woodhead Publishing Limited Abington Hall, Abington Cambridge CB1 6AH. 2001).

[44] R. T, Toledo, Fundamentals of food process engineering. $2^{\text {nd }}$ edition (Aspen Publishers, Inc., 1999).

[45] M. A. Rao, C. Y. Lee, J. Katz, and H. J. Cooley, A kinetic study of the loss of vitamin C, color and firmness during thermal processing of canned peas, Journal of Food Science, 46(2) 1981, 636-637. 